\title{
Polymorphisms Involved in Response to Biological Agents Used in Rheumatoid Arthritis
}

\author{
Giovanni Pallio ${ }^{1} @$, Federica Mannino ${ }^{1}$, Natasha Irrera ${ }^{1}$, Ali H. Eid ${ }^{2}$, Francesco Squadrito ${ }^{1}$ \\ and Alessandra Bitto ${ }^{1, *}$ \\ 1 Department of Clinical and Experimental Medicine, University of Messina, Via C. Valeria, \\ 98125 Messina, Italy; gpallio@unime.it (G.P.); fmannino@unime.it (F.M.); nirrera@unime.it (N.I.); \\ fsquadrito@unime.it (F.S.) \\ 2 Department of Pharmacology and Toxicology, American University of Beirut, Bliss Street, Riad El Solh, \\ 1107-2020 Beirut, Lebanon; ae81@aub.edu.lb \\ * Correspondence: abitto@unime.it; Tel.: +39-090-2213086; Fax: +39-090-2213300
}

Received: 6 July 2020; Accepted: 15 August 2020; Published: 19 August 2020

\begin{abstract}
Rheumatoid arthritis (RA) is a systemic disease that leads to joint destruction. During the last decade, the therapy of RA has been principally based on biological drugs. Although the efficacy of biological therapy has been established, patients demonstrated a high heterogeneity in clinical response to treatment. Several genetic polymorphisms play a part in the different response to biological drugs. This review summarizes the pharmacogenetics of biological agents approved for clinical RA treatment. We reviewed PubMed papers published over the past 20 years (2000-2020), inserting as the search term "rheumatoid arthritis and polymorphisms". Despite some studies showing important correlations between genetic polymorphisms and response to biological therapy in RA patients, most of these findings are still lacking and inconsistent. The personalized treatment according to a pharmacogenetics approach is promising but the available pharmacogenetics data on biological treatment in RA are not adequate and reliable to recommend pharmacogenetic tests before starting biological therapy in RA patients.
\end{abstract}

Keywords: polymorphism; rheumatoid arthritis; TNF- $\alpha$; IL-6; IL-1; CD20; CD80; CD86

\section{Introduction}

Rheumatoid arthritis (RA) is a crippling chronic inflammatory and autoimmune disease. It is characterized by the presence of autoantibodies, systemic inflammation, as well as damage at synovial joints that consequently leads to damage in the articular cartilage. RA affects $0.41-0.52 \%$ of adults in developed countries with 40 per 100,000 new cases annually. Interestingly, this disease is more prevalent in women and elderly people, with smoking being the primary environmental risk factor in the onset of this disease [1,2]. The pathogenesis of RA is characterized by infiltration of fibroblast-like and macrophage-like synoviocytes, macrophages, several populations of $\mathrm{T}$ and $\mathrm{B}$ cells into the synovial tissue, which release pro-inflammatory products (e.g., tumor necrosis factor TNF- $\alpha$ ) but also increase the synovial fluid volume and activate a series of immune responses that lead to the production of autoantibodies that further implement the injury [3,4]. The structurally altered synovia loses its protective role and bone erosion appears, further corrupting the joint. The overproduction of many pro-inflammatory cytokines such as interleukin $1 \beta$ and TNF- $\alpha$, which evoke persistent inflammation and joint destruction, and in particular of IL-6, may contribute not only to the progression of local disease but also to the concomitant hypergammaglobulinemia and thrombocytosis [5]. Several classes of drugs are currently employed for the treatment or management of RA. These include analgesics and non-steroidal anti-inflammatory drugs (NSAIDs) that are primarily used to ameliorate the presented 
symptoms. Nonetheless, these drugs have lost their historical role as first-line treatment largely due to their limited efficacies, inability to modify the long-term course of disease continuum, as well as gastrointestinal and cardiac adverse effects [6]. The other class is disease-modifying antirheumatic drugs (DMARDs), which represent a heterogeneous collection of agents grouped together for use in this disease. These drugs decrease joint-swelling and pain, reduce acute-phase markers and limit progressive joint damage [7].

Before the advent of biologic therapy, most RA cases were treated using a combination of DMARDs; however, for refractory and severe cases, anti-TNF therapy has become a foundation of RA treatment. These anti-TNF biological drugs are divided into two classes: the TNF-receptor fusion protein (certolizumab, etanercept), which prevents TNF action by binding to its cell surface receptor, and TNF-binding monoclonal antibodies (adalimumab, golimumab, and infliximab). Both classes share similar underlying molecular mechanisms, which could then explain their similar effects in modulating inflammatory cytokines levels, complement activation, lymphocyte recruitment, and apoptosis [8,9].

TNF-inhibitors show high efficacy in DMARDs non-responder patients [10]. However, around $30 \%$ of patients do not display clinical improvement following administration of a TNF-inhibitor. RA is a polygenic and multifactorial disease, and thus it is only expected that response to treatment may be influenced by genetic factors. In this context, identifying polymorphisms that can lead to inefficacy of treatment or side effects may be warranted. During recent years, several studies showed contradictory results about the potential association of anti-TNF blocker's response and polymorphisms both in the TNF gene (positions -308, -238, -857, and 489) [11-13] or other related genes such as TNF receptors (TNFR1 and TNFR2) [14]. Furthermore, as previously described, IL-6 inflammatory cascade is involved in RA pathogenesis and its expression has been shown to be modulated by $-174 \mathrm{G} / \mathrm{C}$ polymorphisms in the promoter regions of the IL- 6 gene. In particular, carriers of the $C$ allele showed higher serum levels of IL-6 than carriers of G/G genotype in both the general population and RA patients [15]. Contextually, compared with the G/G genotype, C/C or G/C genotypes are associated with higher severity of RA, due to increased IL-6 production which in turn reduces responsiveness to biological agent therapy $[16,17]$. Moreover, patients with single nucleotide polymorphism (SNP) in +1970 position of the gene coding for IL-1 receptor (IL-1R) exhibited higher levels of this receptor and were more susceptible to developing a severe form of AR [18]. This may explain how the C/C genotype in this SNP could influence the efficacy of biological agent.

A role for other co-stimulatory molecules, CTLA-4, CD28, CD80, and CD86 in the development of rheumatic diseases, has been established. However, polymorphisms of these genes were not significantly associated with RA development or response to treatment $[19,20]$. Additionally, CD20 antigen expressed in B cells is involved in the B-cell depletion with several mechanisms including complement-dependent cytotoxicity and antibody-dependent cell-mediated cytotoxicity, which are influenced by the different affinities of Fc receptor to the Fc fragment of IgG. It has been reported that FCGR3A -158V > F polymorphism was related to the affinity of Fc receptor for IgG. -158 F carrier bound significantly less IgG, than $-158 \mathrm{~V}$ carrier. Consequently, this variation in the affinity of Fc receptor for IgG may affect the differences in clinical response of RA patients to rituximab, a monoclonal antibody against CD20 [21].

In light of all these observations, we review the pharmacogenetic biological treatment of RA, focusing on TNF- $\alpha$, IL6, and anti-CD20.

\section{Methodology}

The database used to retrieve the papers was PubMed and as search terms used were "tumor necrosis factor-alpha and polymorphism and rheumatoid arthritis"; "IL-6 and polymorphism and rheumatoid arthritis"; "IL-1 and polymorphism and rheumatoid arthritis"; "CD80 or CD86 or abatacept and polymorphism and rheumatoid arthritis"; "CD20 or rituximab and polymorphism and rheumatoid arthritis"; "Tofacitinib or upadacitinib or baricitinib and polymorphism and rheumatoid arthritis". Papers published in the last 20 years (2000-2020) showing a significant difference in the response to 
drug treatments were included to provide a broader overview of those genetic variants that affect biological treatment in RA. Papers focusing on SNPs without a significant correlation with clinical outcomes (Disease Activity Score 28 and/or EULAR response) were excluded. Most of the cited papers have been published by European researchers (90\%), although papers from Asian study groups (10\%) have been also taken into account.

\section{Pharmacogenetics and Biological Agents Used in Rheumatoid Arthritis}

\subsection{Pharmacogenetics of TNF- $\alpha$ and TNFR}

In the context of RA treatment, several studies (Table 1) have examined the role of SNPs in the TNF- $\alpha$ gene as a marker of poor response. For instance, Mugnier et al. genotyped 59 patients with RA, stratified them according to their genotype and compared the effect of infliximab treatment after 22 weeks using Disease Activity Score 28 (DAS28 score). The average improvement in the DAS28 score was 1.24 in patients with the A/A and A/G genotype and 2.29 in the G/G patients $(p=0.029)$. These data suggest that patients with a TNF- $\alpha-308 \mathrm{G} / \mathrm{G}$ genotype are better infliximab responders than patients with $\mathrm{A} / \mathrm{A}$ or $\mathrm{A} / \mathrm{G}$ genotypes [22]. In a prospective study of 22 patients with RA who were cured with infliximab, and after 24.8 months of infliximab treatment, patients with the $-308 \mathrm{G} / \mathrm{G}$ genotype showed a decrease in the DAS28 score of $2.4 \pm 0.6$, whereas the $-308 \mathrm{~A} / \mathrm{G}$ group had an increase of $0.12 \pm 0.18(p<0.01)$. These results confirm that RA patients with $-308 \mathrm{G} / \mathrm{G}$ genotype had a significantly better response to infliximab than patients with $-308 \mathrm{~A} / \mathrm{G}$ genotype [23]. Another study genotyped 81 patients with RA treated with adalimumab and evaluated the clinical improvement after 24 weeks of treatment. The DAS28 score improvement at week 24 was $2.5 \pm 1.3$ in the G/G group and $1.8 \pm 1.3$ in the G/A group $(p=0.04)$ [24]. Similarly, others have genotyped 86 patients with RA treated with etanercept and compared clinical response between group with A/G genotype and G/G genotype after 6 months of treatment using DAS28 score. DAS28 improvement was $1.69 \pm 1.31$ in the group of patients with A/G genotype and $2.23 \pm 1.19$ in the group with $\mathrm{G} / \mathrm{G}$ genotype $(p=0.098)$ [25].

Studies employing infliximab, adalimumab, or etanercept have also been conducted in genotyped patients suffering from RA. After 24 weeks of treatment, the average improvement in the DAS28 score was 0.83 in the A/A, 1.50 in the A/G and 2.64 in the $\mathrm{G} / \mathrm{G}$ group respectively $(p<0.0001)$. These results confirmed that patients with TNF- $\alpha-308 \mathrm{G} / \mathrm{G}$ genotype are better responders to anti-TNF-alpha treatment than those with $\mathrm{A} / \mathrm{A}$ or $\mathrm{A} / \mathrm{G}$ genotypes independently to biological agent used [26]. It was interesting then to determine if TNF- $\alpha$ SNPs affect response to treatment. Indeed, it was then showed that a relationship between SNP at TNF-238 or TNF-308 and the different response to treatment founded on the agent used. In particular, patients carrying -308A/A genotype poorly respond to etanercept $(p=0.001)$, whereas this SNP does not associate with response to infliximab [8]. Conversely, the G/A genotype at TNF-238 was associated with a poorer response to infliximab $(p=0.028)$, but not etanercept [8].

There have been several meta-analyses that determined the association between various SNPs and responsiveness to TNF- $\alpha$ inhibitors. One of these studies showed a significant association between the TNF- $\alpha$ promoter $-308 \mathrm{~A} / \mathrm{G}$ polymorphism and responsiveness to anti-TNF therapy, indicating that RA patients with the A allele have a lesser response to anti-TNF agent than individuals with the $G$ allele [27]. Another meta-analysis of nine studies with a total of 692 patients showed that the presence of an A allele in position -308 significantly decreases the response to TNF- $\alpha$ inhibitors [28]. Likewise, a meta-analysis of 15 studies with a total of 2127 patients concluded that carrying the $G$ allele in position -308 is associated with a stronger response to biological treatment than the A/A genotype [29].

Various other studies have looked into the effects of other SNPs. For instance, a study looking at the $-857 \mathrm{C} / \mathrm{T}$ polymorphism in 70 patients treated with etanercept showed that RA patients whit the $\mathrm{T}$ allele $(\mathrm{T} / \mathrm{T}$ or $\mathrm{C} / \mathrm{T})$ respond better to etanercept therapy than homozygotes for the $\mathrm{C}$ allele $(\mathrm{C} / \mathrm{C})$. This indicates that this SNP may become a possible genetic marker for predicting anti-TNF therapeutic effects [30]. Studying three TNF- $\alpha$ gene polymorphisms (-238 A/G, -308 A/G and -857 C/T) showed 
that the $-238 \mathrm{G},-308 \mathrm{G}$, or $-857 \mathrm{C}$ haplotype in a homozygous form was significantly associated with a lower ACR50 response to adalimumab [31].

SNPs in the TNFR are also associated with responsiveness. Indeed, in RA patients on anti-TNF- $\alpha$ therapy after 3 months, the TNFR1 36 A/A genotype was associated with a worse DAS-based European League Against Rheumatism (EULAR) response than A/G or G/G genotype to $(p=0.04)$ [14]. Moreover, RA patients with TNFR2 rs1061622 T allele had a worst response to anti-TNF therapy compared to patients with the TNFR2 rs1061622 G allele ( $p=0.045)$ [32]. Similarly, TNFR2 3397C/C, TNFR2 rs1061622 G/G, and TNFR2 rs1061631 A/A genotypes had an increased risk of having a poorer response to anti-TNF drugs ( $p=0.014, p=0.0085$ and $p=0.028$ respectively) [33]. Patients with TNFR2 676 T/G genotype was significantly associated with lower ACR response compared to patients with $676 \mathrm{~T} / \mathrm{T}$ genotype, after 3 and 12 months of treatment [34].

There are some studies that looked at a combination of SNPs in both the receptor and the TNF gene. In a study that enrolled $58 \mathrm{RA}$ patients receiving infliximab, six polymorphisms, 36A $>\mathrm{G}$ in TNFR1; 676T > G in TNFR2; -857C > T, -308G > A, -238G > A and 489G > A in TNF- $\alpha$ gene and their relationship to therapeutic efficacy were determined. This study showed that a combination of $676 \mathrm{~T}>\mathrm{G}$ (TNFR2) and $-857 \mathrm{C}>\mathrm{T}(\mathrm{TNF}-\alpha)$ could influence infliximab therapeutic efficacy in RA patients [35]. Similarly, in 280 RA patients treated with TNF-inhibitors, an association study of five SNPs in TNF- $\alpha$ and TNF-receptor encoding genes (TNF- $\alpha$ : $-308 \mathrm{G}>\mathrm{A},-238 \mathrm{G}>\mathrm{A},-857 \mathrm{C}>\mathrm{T}$; TNFR1 36A > G; TNFR2 676T > G) was investigated. After 3 months of treatment, patients with the TNFR1 36 A/A genotype achieved a good EULAR response compared to patients carrying the G allele $(p=0.011)$. After 6 months low disease activity was observed in patients with TNFR1 36 A/A genotype than patients with $\mathrm{G} / \mathrm{G}$ genotype $(p=0.04)$. Moreover, after 6 months DAS28 score was significantly lower in the subgroup of patients with TNF- $\alpha-857$ T/T genotype compared to C allele carriers $(p=0.012)$ [36].

In summary, treatments are affected mainly by the presence of the G allele in -308 TNF- $\alpha$ polymorphism carriers disregarding of the anti-TNF used (Table 1). Moreover, the presence of polymorphic sites on TNF- $\alpha$ receptors was also associated with a better response of treated patients, suggesting that a pre-evaluation could be useful for prescribing the most useful drug, according to patient's genetic profile.

Table 1. Summary of studies on pharmacogenetics of anti-TNF treatment in RA.

\begin{tabular}{|c|c|c|c|}
\hline Study & Polymorphic Locus & Biological Agent & Clinical Effects \\
\hline Mugnier et al. 2003 & TNF- $\alpha-308$ & Infliximab & $\begin{array}{l}\text { TNF- } \alpha-308 \mathrm{G} / \mathrm{G} \text { was associated with } \\
\text { better response than TNF- } \alpha-308 \mathrm{G} / \mathrm{A} \\
\text { or A/A }\end{array}$ \\
\hline Fonseca et al. 2005 & TNF- $\alpha-308$ & Infliximab & $\begin{array}{l}\text { TNF- } \alpha-308 \mathrm{G} / \mathrm{G} \text { was associated with } \\
\text { better response than TNF- } \alpha-308 \mathrm{G} / \mathrm{A}\end{array}$ \\
\hline Cuchacovich et al. 2006 & TNF- $\alpha-308$ & Adalimumab & $\begin{array}{l}\text { TNF- } \alpha-308 \mathrm{G} / \mathrm{G} \text { was associated with } \\
\text { better response than TNF- } \alpha-308 \mathrm{G} / \mathrm{A}\end{array}$ \\
\hline Guis et al. 2007 & TNF- $\alpha-308$ & Etanercept & $\begin{array}{l}\text { TNF- } \alpha-308 \mathrm{G} / \mathrm{G} \text { was associated with } \\
\text { better response than TNF- } \alpha-308 \mathrm{G} / \mathrm{A}\end{array}$ \\
\hline Seitz et al. 2007 & TNF- $\alpha-308$ & $\begin{array}{l}\text { Infliximab-Adalimumab- } \\
\text { Etanercept }\end{array}$ & $\begin{array}{l}\text { TNF- } \alpha-308 \mathrm{G} / \mathrm{G} \text { was associated with } \\
\text { better response than } \mathrm{A} / \mathrm{A} \text { or } \mathrm{A} / \mathrm{G} \\
\text { independently to biological agent used }\end{array}$ \\
\hline Kang et al. 2005 & TNF- $\alpha-857$ & Etanercept & $\begin{array}{c}\text { TNF- } \alpha-857 \mathrm{~T} / \mathrm{T} \text { or } \mathrm{C} / \mathrm{T} \text { were associated } \\
\text { with better response than TNF- } \alpha \\
-857 \mathrm{C} / \mathrm{C}\end{array}$ \\
\hline Miceli-Richard et al. 2008 & $\begin{array}{c}\text { TNF- } \alpha-238 \text { TNF- } \alpha-308 \\
\text { TNF- } \alpha-857\end{array}$ & Adalimumab & $\begin{array}{l}\text { TNF- } \alpha-238 \mathrm{G} /-308 \mathrm{G} /-857 \mathrm{C} \text { haplotype } \\
\text { in a homozygous form was associated } \\
\text { with a lower response }\end{array}$ \\
\hline Ongaro et al. 2008 & TNFR2 & $\begin{array}{l}\text { Infliximab-Adalimumab- } \\
\text { Etanercept }\end{array}$ & $\begin{array}{l}\text { TNFR2 } 676 \mathrm{~T} / \mathrm{T} \text { was associated with a } \\
\text { better response compared to } 676 \mathrm{~T} / \mathrm{G}\end{array}$ \\
\hline Swierkot et al. 2015 & TNF- $\alpha$ FR1 TNFR2 & $\begin{array}{l}\text { Infliximab-Adalimumab- } \\
\text { Etanercept }\end{array}$ & $\begin{array}{l}\text { TNFR1 } 36 \mathrm{~A} / \mathrm{A} \text { was associated with } \\
\text { better response than } \mathrm{G} / \mathrm{G} \text {. } \\
\text { TNF- } \alpha-857 \mathrm{~T} / \mathrm{T} \text { showed better } \\
\text { response than } \mathrm{C} \text { allele carriers }\end{array}$ \\
\hline
\end{tabular}




\subsection{Pharmacogenetics of Interleukin-6 and Interleukin-6R and Their Influence on Anti-TNF and Anti-CD20 Therapy in $R A$}

The IL-6 inflammatory cascade is involved in RA pathogenesis. Hence, antibodies targeting IL-6R, such as tocilizumab and sarilumab, were used for the treatment of RA. Although limited, there are a few studies that investigated the role of genetic variations in response to these biological treatments. For instance, three IL-6R, SNPs 8435A > G rs12083537, 54302A > C rs8192284 and 59752T $>$ C rs4329505, were investigated in 79 RA patients. Results showed that the presence of the AAC haplotype (for rs12083537, rs8192284, and rs4329505) was associated with a poor SJC (swollen joint count) and EULAR response ( $p=0.00004 ; p=0.05$ respectively) [37]. Another study investigated the influence of rs12083537, rs2228145, rs4329505 and rs11265618 SNPs in IL-6R on response to tocilizumab in 77 RA patients [38]. This study showed that the A/A genotype for rs12083537 $(p=0.004)$ and C/C genotype for rs11265618 ( $p=0.004$ ) had better LDA (low disease activity) response after 12 months of treatment [38]. Moreover, a recent paper confirmed that the response to tocilizumab was associated with SNPs in the IL-6R gene. Patients with A/A genotype for rs12083537 showing a significantly better response than homozygous or heterozygous patients with the G allele $(p=0.018)$ [39].

Polymorphisms in IL-6 promoter may also affect response to anti-TNF agent. For instance, in a cohort of 77 RA patients, a relationship between disease activity and the $-174 \mathrm{G}>\mathrm{C}$ IL- 6 gene promoter polymorphism before and after etanercept therapy was noted. Indeed, after 12 months of treatment, the percentage of patients responding to treatment was significantly higher in patients with $\mathrm{G} / \mathrm{G}$ genotype (95.7\%) compared to patients with the G/C (75.6\%) or C/C (44.4\%) genotype $(p=0.006)$ [17]. These results were confirmed by another study showing that patients receiving anti-TNF therapy had a significant correlation between the IL-6 -174G allele and a good or moderate EULAR response at 12, 18 and 24 months [40]. Furthermore, this was supported by a meta-analysis which showed that patients carrying the IL-6 -174C allele have a poorer response to anti-TNF therapy for RA [41]. Contextually, after 12 months of etanercept therapy, patients with the combined IL-6 - 174 G/G and TNF- $\alpha-308$ G/G genotype were, more frequently, responders to treatment (DAS28 improvement $>1.2$ ) compared to patients with other combined genotypes $(p=0.022)$ [42].

Rituximab, a chimeric monoclonal antibody against CD20, has also been used to treat RA patients. A relationship between various SNPs and responsiveness to rituximab in RA patients has been reported. In particular, polymorphisms in the promoter of IL-6 may also affect response to rituximab. Moreover, C/C homozygosis of the -174 IL-6 promoter polymorphism appears to be a predictor of no response to rituximab in RA patients $[43,44]$.

In summary, IL-6R $8435 \mathrm{~A} / \mathrm{A}$ genotype was associated with better response to tocilizumab. Moreover, IL-6 -174 G/G genotype was associated with better response to anti-TNF agent (infliximab, adalimumab, etanercept) and anti-CD20 rituximab (Table 2), suggesting that a pharmacogenetic pre-evaluation of patients could be useful for a targeted treatment of RA patients.

\subsection{Pharmacogenetics and Anti-CD20 Treatment}

Several studies demonstrated that the efficacy of anti-CD20 treatment varies inter-individually. For instance, FCGR3A -158V allele was significantly associated with a higher response rate to rituximab treatment in patients with RA who did not respond or tolerate anti-TNF therapy [45]. Similarly, in another study, heterozygous patients (FCGR3A-158VF) showed higher rate of responsiveness to rituximab [46]. Moreover, in $-158 \mathrm{~V} / \mathrm{V}$ patients the response rate differed between male and female patients $(p=0.036)$ demonstrating that the impact of $-158 \mathrm{~V} / \mathrm{V}$ genotype on rituximab response may be influenced by sex [46]. In another study involving $212 \mathrm{RA}$ patients, the FCGR3A -158 V/V genotype was associated with higher ratio (89.5\%) of EULAR response (good or moderate) at 6 months compared to $\mathrm{V} / \mathrm{F}(66 \%)$ or $\mathrm{F} / \mathrm{F}(66.2 \%)$ [47]. A low disease activity score was achieved in patients with $\mathrm{V} / \mathrm{V}(62.5 \%$ $p=0.030)$ or $\mathrm{V} / \mathrm{F}(64.7 \% p=0.015)$ compared with $\mathrm{F} / \mathrm{F}$ subjects $(30.0 \%)$ [48].

Other SNPs of various genes have also been studied in the context of RA and rituximab. One study analyzed 13 SNPs located in genes coding for IL-10, LTA, TGF $\beta 1$, TNF- $\alpha$, TNFR2, -C5 TRAF1, 
STAT4, TNFAIP3, and PTPN22. Only TGF $\beta 110 \mathrm{C} / \mathrm{T}$ genotype and TGF $\beta 125 \mathrm{G} / \mathrm{C}$ genotype were associated with a better clinical response [49]. Moreover, polymorphisms on B-cell-activating factor (BAFF) gene, coding for a cytokine with an important role in B-cell stimulation were associated with rituximab response. Indeed, in a study involving $115 \mathrm{RA}$ patients, BAFF $-871 \mathrm{C}>\mathrm{T}$ polymorphism correlation with EULAR response after 24 weeks of rituximab treatment was evaluated. This study showed that the $\mathrm{C} / \mathrm{C}$ genotype was significantly associated with a higher response rate $(92 \%)$ than the $\mathrm{T} / \mathrm{T}$ genotype (64\%). The positive association between the presence of a $\mathrm{C}$ allele and good response to rituximab treatment was further confirmed in a multivariate analysis, where carriage of this allele was independently correlated with higher response to rituximab [50]. Additionally, the effects of TTTT BAFF haplotype on response to rituximab therapy in RA patients showed that this haplotype was more recurrent in good (41.9\%) than in moderate responders (24.1\%) [51]. Furthermore, multivariate analysis confirmed that TTTT BAFF promoter haplotype is an independent marker of good response to rituximab treatment in RA patients [51]. Moreover, Jiménez Morales and colleagues investigated the influence of FCGR2A/FCGR3A gene polymorphisms in 55 RA patients treated with rituximab according to low disease activity rate and DAS 28 score at $6,12,18$ months. Carriers of the FCGR2A rs1801274-TT genotype had higher EULAR response at $6(p=0.035)$ and 12 months $(p=0.066)$ and a greater improvement in DAS28 score at $12(p=0.098)$ and 18 months $(p=0.025)$. The FCGR3A rs396991-G allele was associated with improved low disease activity rate $(p=0.077)$ and a greater improvement in DAS28 score $(p=0.021)$ at 18 months [52].

In summary, rituximab efficacy is affected mainly by the presence of FCGR3A $-158 \mathrm{~V}$ allele. Moreover, BAFF $-871 \mathrm{C} / \mathrm{C}$ genotype was also associated with a better response of RA patients treated with rituximab, suggesting that a pharmacogenetics pre-evaluation could be useful to improve the efficacy of these biological treatments in RA patients (Table 2).

\subsection{Pharmacogenetics of $C D 80$ and $C D 86$}

Abatacept is a recombinant fusion protein composed of the Fc region of the immunoglobulin IgG1 fused to the extracellular domain of cytotoxic T-lymphocyte-associated antigen 4 (CTLA4). CTLA4-Ig acts as a competitive inhibitor of CD28 on the T-cell surface by binding with either CD80 (ligand B7-1) or CD86 (ligand B7-2) on the antigen-presenting cell [53]. Blocking CD80 or CD86 prevents the second signal, without which T-cell activation would be hindered. Abatacept is clinically used for the treatment of RA patients with unsatisfactory response to traditional DMARDs or TNF antagonists. To date, only one study examined the role of genetic polymorphisms in the treatment efficacy in RA patients; however, the results are of no clinical relevance (Table 2). In fact, SNPs in CTLA4 gene do not predict the response to abatacept [20].

\subsection{Pharmacogenetics of Interleukin-1}

Anakinra is a recombinant IL-1 receptor (IL1-R) antagonist. To the best of our knowledge, only one study examined the association between IL-1 genotype and the treatment response to anti-IL-1 therapy. Importantly, a significant association was found between carriage of the minor allele IL- $1 \alpha$ $(+4845)$ and response to treatment [54]. Moreover, a slighter association was found for carriage of the minor allele IL-1 $\beta$ (+3954) and anakinra treatment. Interestingly, a highly significant association between treatment outcome and the haplotype IL1 $\alpha(+4845)$ and IL1 $\beta(+3954)$ was noted [54]. 
Table 2. Summary of studies on pharmacogenetics of anti-Interleukin-6, anti-CD20, anti-Interleukin-1 treatments in RA.

\begin{tabular}{|c|c|c|c|}
\hline Study & Polymorphic Locus & Biological Agent & Clinical Effects \\
\hline Enevold et al. 2014 & $\begin{array}{l}\text { IL-6R rs12083537; } \\
\text { rs8192284; rs4329505 }\end{array}$ & Tocilizumab & $\begin{array}{l}\text { AAC-haplotype for rs12083537; } \\
\text { rs2228145; rs4329505, was } \\
\text { associated with a poor SJC and } \\
\text { EULAR response }\end{array}$ \\
\hline $\begin{array}{l}\text { Maldonado-Montoro } \\
\text { et al. } 2016\end{array}$ & $\begin{array}{l}\text { IL-6R rs12083537; } \\
\quad \text { rs11265618 }\end{array}$ & Tocilizumab & $\begin{array}{c}\text { rs12083537 A/A and rs11265618 C/C } \\
\text { were associated with better } \\
\text { EULAR response }\end{array}$ \\
\hline $\begin{array}{l}\text { Luxembourger et al. } \\
2019\end{array}$ & IL-6R rs12083537 & Tocilizumab & $\begin{array}{l}\text { rs12083537 A/A was associated with } \\
\text { better response than } A / G \text { or } G / G\end{array}$ \\
\hline Jančić et al. 2013 & IL-6 -174 & Etanercept & $\begin{array}{l}\text { IL-6 - } 174 \mathrm{G} / \mathrm{G} \text { was associated with } \\
\text { better response than } \mathrm{G} / \mathrm{C} \text { or } \mathrm{C} / \mathrm{C}\end{array}$ \\
\hline Davila-Fajardo et al. 2014 & IL-6 -174 & $\begin{array}{l}\text { Infliximab-Adalimumab- } \\
\text { Etanercept }\end{array}$ & $\begin{array}{l}\text { IL- } 6-174 \mathrm{G} / \mathrm{G} \text { was associated with } \\
\text { better response than } \mathrm{G} / \mathrm{C} \text { or } \mathrm{C} / \mathrm{C}\end{array}$ \\
\hline Quartuccio et al. 2014 & FCGR3A -158 & Rituximab & $\begin{array}{c}\text { The FCGR3A }-158 \mathrm{~V} / \mathrm{V} \mathrm{G} \text { was } \\
\text { associated with better response than } \\
\mathrm{V} / \mathrm{F} \text { or } \mathrm{F} / \mathrm{F}\end{array}$ \\
\hline Pai et al. 2017 & FCGR3A -158 & Rituximab & $\begin{array}{c}\text { The FCGR3A }-158 \mathrm{~V} / \mathrm{V} \text { and } \mathrm{V} / \mathrm{F} \\
\text { were associated with better response } \\
\text { than } \mathrm{F} / \mathrm{F}\end{array}$ \\
\hline $\begin{array}{l}\text { Jiménez Morales et al. } \\
\qquad 2019\end{array}$ & $\begin{array}{c}\text { FCGR2A } 9541 \\
\text { FCGR3A } 10872\end{array}$ & Rituximab & $\begin{array}{l}\text { The FCGR2A 9541TT genotype was } \\
\text { associated with higher EULAR } \\
\text { response. The FCGR3A 10,872 G } \\
\text { allele was associated with a greater } \\
\text { improvement in DAS28 score }\end{array}$ \\
\hline
\end{tabular}

\subsection{Pharmacogenetics of Janus Kinase (JAK)}

Tofacitinib, upadacitinib and baricitinib are orally administered Janus kinase (JAK) inhibitor, used to treat RA. To date there are no studies examining the associations between SNPs and treatment outcome of RA patients with these biological drugs.

\section{Conclusions}

Several pharmacogenetic studies investigated associations between SNPs and response to biological treatment in RA. The candidate genes for SNPs study were chosen from the genes involved in RA cytokines signaling cascade. Numerous papers have reported that some SNPs might have a linkage to biological treatment response and could have a potential role as possible predictors of response in particular for TNF- $\alpha$ inhibitors, anti-IL-6R drugs, and CD20 inhibitor. On the other hand, these associations have been rarely confirmed in large cohorts of patients or meta-analysis studies to indicate the weakness of these associations. Moreover, to date there are few studies investigating the associations between SNPs and clinical outcome of RA patients treated with anti-CD80 and CD86, anti-Interleukin-1R, or Janus kinase (JAK) inhibitors. Presently, from the clinical perspective, the most suitable way to move forward in the management of RA patients is to improve TNF- $\alpha$ pharmacogenomics, considering in the next studies bias such as ethnicity, different criteria to define clinical responder or different kinds of biological agents used that could influence the clinical results and the scientific value of investigations. From these speculations arises the importance of using genetic analysis to switch the personalized biological therapy of RA patients from an empiric strategy into a sound and cost-effective clinical practice. 
Author Contributions: Conceptualization, G.P. and A.B.; Writing-Original Draft Preparation, G.P.; Writing-Review and Editing, F.M., N.I., A.H.E., F.S.; Supervision, A.B. All authors have read and agreed to the published version of the manuscript.

Funding: This work was supported by departmental funding assigned to Professor Alessandra Bitto.

Conflicts of Interest: The authors declare no conflict of interest.

\section{References}

1. Hunter, T.M.; Boytsov, N.N.; Zhang, X.; Schroeder, K.; Michaud, K.; Araujo, A.B. Prevalence of rheumatoid arthritis in the United States adult population in healthcare claims databases, 2004-2014. Rheumatol. Int. 2017, 37, 1551-1557. [CrossRef]

2. Carlens, C.; Hergens, M.-P.; Grunewald, J.; Ekbom, A.; Eklund, A.; Höglund, C.O.; Askling, J. Smoking, Use of Moist Snuff, and Risk of Chronic Inflammatory Diseases. Am. J. Respir. Crit. Care Med. 2010, 181, 1217-1222. [CrossRef]

3. Scott, D.L.; Steer, S. The course of established rheumatoid arthritis. Best Pr. Res. Clin. Rheumatol. 2007, 21, 943-967. [CrossRef]

4. Scott, D.L.; Wolfe, F.; Huizinga, T.W. Rheumatoid arthritis. Lancet 2010, 376, 1094-1108. [CrossRef]

5. Choy, E.H.S.; Isenberg, D.A.; Garrood, T.; Farrow, S.; Ioannou, Y.; Bird, H.; Cheung, N.; Williams, B.; Hazleman, B.; Price, R.; et al. Therapeutic benefit of blocking interleukin-6 activity with an anti-interleukin-6 receptor monoclonal antibody in rheumatoid arthritis: A randomized, double-blind, placebo-controlled, dose-escalation trial. Arthritis Rheum. 2002, 46, 3143-3150. [CrossRef]

6. Schaffer, D.; Florin, T.; Eagle, C.; Marschner, I.C.; Singh, G.; Grobler, M.; Fenn, C.; Schou, I.M.; Curnow, K.M. Risk of serious NSAID-related gastrointestinal events during long-term exposure: A systematic review. Med. J. Aust. 2006, 185, 501-506. [CrossRef]

7. Donahue, K.E.; Gartlehner, G.; Jonas, D.E.; Lux, L.J.; Thieda, P.; Hansen, R.A.; Morgan, L.C.; Lohr, K.N. Systematic Review: Comparative Effectiveness and Harms of Disease-Modifying Medications for Rheumatoid Arthritis. Ann. Intern. Med. 2008, 148, 124. [CrossRef] [PubMed]

8. Maxwell, J.R.; Potter, C.; Hyrich, K.L.; Barton, A.; Worthington, J.; Isaacs, J.D.; Morgan, A.W.; Wilson, A.G. Braggss Association of the tumour necrosis factor-308 variant with differential response to anti-TNF agents in the treatment of rheumatoid arthritis. Hum. Mol. Genet. 2008, 17, 3532-3538. [CrossRef] [PubMed]

9. Gudbrandsdottir, S.; Larsen, R.; Sørensen, L.K.; Nielsen, S.; Hansen, M.B.; Svenson, M.; Bendtzen, K.; Müller, K. TNF and LT binding capacities in the plasma of arthritis patients: Effect of etanercept treatment in juvenile idiopathic arthritis. Clin. Exp. Rheumatol. 2004, 22, 118-124.

10. Rein, P.; Mueller, R.B. Treatment with Biologicals in Rheumatoid Arthritis: An Overview. Rheumatol. Ther. 2017, 4, 247-261. [CrossRef] [PubMed]

11. Scardapane, A.; Ferrante, R.; Nozzi, M.; Savino, A.; Antonucci, I.; Dadorante, V.; Balsamo, M.; Stuppia, L.; Chiarelli, F.; Breda, L. TNF- $\alpha$ gene polymorphisms and juvenile idiopathic arthritis: Influence on disease outcome and therapeutic response. Semin. Arthritis Rheum. 2015, 45, 35-41. [CrossRef] [PubMed]

12. Pavy, S.; Toonen, E.J.M.; Miceli-Richard, C.; Barrera, P.; Van Riel, P.L.C.M.; Criswell, L.A.; Mariette, X.; Coenen, M.J.H. Tumour necrosis factor $\alpha-308 \mathrm{G} \rightarrow \mathrm{A}$ polymorphism is not associated with response to $\mathrm{TNF} \alpha$ blockers in Caucasian patients with rheumatoid arthritis: Systematic review and meta-analysis. Ann. Rheum. Dis. 2009, 69, 1022-1028. [CrossRef] [PubMed]

13. Murdaca, G.; Gulli, R.; Spanò, F.; Lantieri, F.; Burlando, M.; Parodi, A.; Mandich, P.; Puppo, F. TNF- $\alpha$ Gene Polymorphisms: Association with Disease Susceptibility and Response to Anti-TNF- $\alpha$ Treatment in Psoriatic Arthritis. J. Investig. Dermatol. 2014, 134, 2503-2509. [CrossRef] [PubMed]

14. Morales-Lara, M.J.; Cañete, J.D.; Torres-Moreno, D.; Hernández, M.V.; Pedrero, F.; Celis, R.; García-Simón, M.S.; Conesa-Zamora, P. Effects of polymorphisms in TRAILR1 and TNFR1A on the response to anti-TNF therapies in patients with rheumatoid and psoriatic arthritis. Jt. Bone Spine 2012, 79, 591-596. [CrossRef] [PubMed]

15. Panoulas, V.F.; Stavropoulos-Kalinoglou, A.; Metsios, G.S.; Smith, J.P.; Milionis, H.J.; Douglas, K.M.J.; Nightingale, P.; Kitas, G.D. Association of interleukin-6 (IL-6)-174G/C gene poly-morphism with cardiovascular disease in patients with rheumatoid arthritis: The role of obesity and smoking. Atherosclerosis 2009, 204, 178-183. [CrossRef] [PubMed] 
16. Ceccarelli, F.; Perricone, C.; Fabris, M.; Alessandri, C.; Iagnocco, A.; Fabro, C.; Pontarini, E.; De Vita, S.; Valesini, G. Transforming growth factor $\beta$ 869C/T and interleukin 6-174G/C polymorphisms relate to the severity and progression of bone-erosive damage detected by ultrasound in rheumatoid arthritis. Arthritis Res. Ther. 2011, 13, R111. [CrossRef]

17. Jančić, I.; Arsenović-Ranin, N.; Sefik-Bukilica, M.; Živojinović, S.; Damjanov, N.; Spasovski, V.; Srzentic, S.; Stanković, B.; Pavlović, S. 174G/C interleukin-6 gene promoter polymorphism predicts therapeutic response to etanercept in rheumatoid arthritis. Rheumatol. Int. 2012, 33, 1481-1486. [CrossRef]

18. Mahmoudi, M.; Amirzargar, A.; Jamshidi, A.; Farhadi, E.; Noori, S.; Avraee, M.; Nazari, B.; Nicknam, M.H. Association of IL1R polymorphism with HLA-B27 positive in Iranian patients with ankylosing spondylitis. Eur. Cytokine Netw. 2011, 22, 175-180. [CrossRef]

19. Matsushita, M.; Tsuchiya, N.; Oka, T.; Yamane, A.; Tokunaga, K. New polymorphisms of human CD80 and CD86: Lack of association with rheumatoid arthritis and systemic lupus erythematosus. Genes Immun. 2000, 1, 428-434. [CrossRef]

20. Talotta, R.; Bagnato, G.L.; Atzeni, F.; Ditto, M.C.; Bitto, A.; Squadrito, F.; Gullo, A.L.; Sarzi-Puttini, P. Polymorphic alleles in exon 1 of the CTLA4 gene do not predict the response to abatacept. Clin. Exp. Rheumatol. 2013, 31, 813.

21. Weiner, G.J. Rituximab: Mechanism of Action. Semin. Hematol. 2010, 47, 115-123. [CrossRef] [PubMed]

22. Mugnier, B.; Balandraud, N.; Darque, A.; Roudier, C.; Roudier, J.; Reviron, D. Polymorphism at position-308 of the tumor necrosis factor $\alpha$ gene influences outcome of infliximab therapy in rheumatoid arthritis. Arthritis Rheum. 2003, 48, 1849-1852. [CrossRef] [PubMed]

23. Fonseca, J.E.; Carvalho, T.; Cruz, M.; Nero, P.; Sobral, M.; Mourão, A.F.; Cavaleiro, J.; Ligeiro, D.; Abreu, I.; Carmo-Fonseca, M.; et al. Polymorphism at position-308 of the tumour necrosis factor $\alpha$ gene and rheumatoid arthritis pharmacogenetics. Ann. Rheum. Dis. 2005, 64, 793-794. [CrossRef] [PubMed]

24. Cuchacovich, M.; Soto, L.; Edwardes, M.; Gutierrez, M.; Llanos, C.; Pacheco, D.; Sabugo, F.; Alamo, M.; Fuentealba, C.; Villanueva, L.; et al. Tumour necrosis factor (TNF) $\alpha-308$ G/G promoter polymorphism and $\mathrm{TNF} \alpha$ levels correlate with a better response to adalimumab in patients with rheumatoid arthritis. Scand. J. Rheumatol. 2006, 35, 435-440. [CrossRef]

25. Guis, S.; Balandraud, N.; Bouvenot, J.; Auger, I.; Toussirot, E.; Wendling, D.; Mattei, J.P.; Nogueira, L.; Mugnier, B.; Legeron, P.; et al. Influence of -308 A/G polymorphism in the tumor necrosis factor $\alpha$ gene on etanercept treatment in rheumatoid arthritis. Arthritis Rheum. 2007, 57, 1426-1430. [CrossRef]

26. Seitz, M.; Wirthmüller, U.; Möller, B.; Villiger, P.M. The 308 tumour necrosis factor-gene polymorphism predicts therapeutic response to TNF-blockers in rheumatoid arthritis and spondyloarthritis patients. Rheumatology 2007, 46, 93-96. [CrossRef]

27. Lee, Y.H.; Rho, Y.H.; Choi, S.J.; Ji, J.D.; Song, G.G. Association of TNF-alpha-308 G/A polymorphism with responsiveness to TNF- $\alpha$-blockers in rheumatoid arthritis: A meta-analysis. Rheumatol. Int. 2006, 27, 157-161. [CrossRef]

28. O’Rielly, D.D.; Roslin, N.M.; Beyene, J.; Pope, A.; Rahman, P. TNF- $\alpha-308$ G/A polymorphism and responsiveness to TNF- $\alpha$ blockade therapy in moderate to severe rheumatoid arthritis: A systematic review and meta-analysis. Pharm. J. 2009, 9, 161-167. [CrossRef]

29. Zeng, Z.; Duan, Z.; Zhang, T.; Wang, S.; Li, G.; Gao, J.; Ye, D.; Xu, S.; Xu, J.; Zhang, L.; et al. Association between tumor necrosis factor- $\alpha$ (TNF- $\alpha$ ) promoter-308 G/A and response to TNF- $\alpha$ blockers in rheumatoid arthritis: A meta-analysis. Mod. Rheumatol. 2013, 23, 489-495. [CrossRef]

30. Kang, C.-W.; Lee, K.W.; Yoo, D.H.; Bae, S.-C. The influence of a polymorphism at position -857 of the tumour necrosis factor gene on clinical response to etanercept therapy in rheumatoid arthritis. Rheumatology 2005, 44, 547-552. [CrossRef]

31. Miceli-Richard, C.; Comets, E.; Verstuyft, C.; Tamouza, R.; Loiseau, P.; Ravaud, P.; Kupper, H.; Becquemont, L.; Charron, M.; Mariette, X. A single tumour necrosis factor haplotype influences the response to adalimumab in rheumatoid arthritis. Ann. Rheum. Dis. 2007, 67, 478-484. [CrossRef] [PubMed]

32. Chen, W.; Xu, H.; Wang, X.; Gu, J.; Xiong, H.; Shi, Y. The tumor necrosis factor receptor superfamily member 1B polymorphisms predict response to anti-TNF therapy in patients with autoimmune disease: A meta-analysis. Int. Immunopharmacol. 2015, 28, 146-153. [CrossRef] [PubMed] 
33. Canet, L.M.; Filipescu, I.; Cáliz, R.C.; Lupiañez, C.B.; Canhão, H.; Escudero, A.; Segura-Catena, J.; Soto-Pino, M.J.; Ferrer, M.; García, A.; et al. Genetic variants within the TNFRSF1B gene and susceptibility to rheumatoid arthritis and response to anti-TNF drugs. Pharmacogenetics Genom. 2015, 25, 1-333. [CrossRef] [PubMed]

34. Ongaro, A.; De Mattei, M.; Pellati, A.; Caruso, A.; Ferretti, S.; Masieri, F.F.; Fotinidi, M.; Farina, I.; Trotta, F.; Padovan, M. Can tumor necrosis factor receptor II gene $676 \mathrm{~T}>\mathrm{G}$ polymorphism predict the response grading to anti-TNFalpha therapy in rheumatoid arthritis? Rheumatol. Int. 2008, 28, 901-908. [CrossRef] [PubMed]

35. Chatzikyriakidou, A.; Georgiou, I.; Voulgari, P.V.; Venetsanopoulou, A.I.; Drosos, A.A. Combined tumour necrosis factor- and tumour necrosis factor receptor genotypes could predict rheumatoid arthritis patients' response to anti-TNF-therapy and explain controversies of studies based on a single polymorphism. Rheumatology 2007, 46, 1034-1035. [CrossRef]

36. Swierkot, J.; Bogunia-Kubik, K.; Nowak, B.; Bialowas, K.; Korman, L.; Gębura, K.; Kolossa, K.; Jeka, S.; Wiland, P. Analysis of associations between polymorphisms within genes coding for tumour necrosis factor (TNF)-alpha and TNF receptors and responsiveness to TNF-alpha blockers in patients with rheumatoid arthritis. Jt. Bone Spine 2015, 82, 94-99. [CrossRef]

37. Enevold, C.; Baslund, B.; Linde, L.; Josephsen, N.L.; Tarp, U.; Lindegaard, H.M.; Jacobsen, S.; Nielsen, C.H. Interleukin-6-receptor polymorphisms rs12083537, rs2228145, and rs4329505 as predictors of response to tocilizumab in rheumatoid arthritis. Pharm. Genom. 2014, 24, 1. [CrossRef]

38. Maldonado-Montoro, M.; Cañadas-Garre, M.; González-Utrilla, A.; Calleja-Hernández, M. Ángel Influence of IL6R gene polymorphisms in the effectiveness to treatment with tocilizumab in rheumatoid arthritis. Pharm. J. 2016, 18, 167-172. [CrossRef]

39. Luxembourger, C.; Ruyssen-Witrand, A.; Ladhari, C.; Rittore, C.; Degboé, Y.; Maillefert, J.-F.; Gaudin, P.; Marotte, H.; Wendling, D.; Jorgensen, C.; et al. A single nucleotide polymorphism of IL6-receptor is associated with response to tocilizumab in rheumatoid arthritis patients. Pharm. J. 2019, 19, 368-374. [CrossRef]

40. Dávila-Fajardo, C.L.; Marquez, A.; Pascual-Salcedo, D.; Ramos, M.J.M.; García-Portales, R.; Magro, C.; Alegre-Sancho, J.J.; Balsa, A.; Cabeza-Barrera, J.; Raya, E.; et al. Confirmation of 174G/C interleukin-6 gene promoter polymorphism as a genetic marker predicting antitumor necrosis factor treatment outcome. Pharm. Genom. 2014, 24, 1-5. [CrossRef]

41. Lee, Y.H.; Bae, S.-C.; Song, G.G. Functional FCGR3A 158 V/F and IL-6 -174 C/G polymorphisms predict response to biologic therapy in patients with rheumatoid arthritis: A meta-analysis. Rheumatol. Int. 2014, 34, 1409-1415. [CrossRef] [PubMed]

42. Jančić, I.; Sefik-Bukilica, M.; Živojinović, S.; Damjanov, N.; Spasovski, V.; Kotur, N.; Klaassen, K.; Pavlović, S.; Bufan, B.; Arsenović-Ranin, N. Influence Of Promoter Polymorphisms Of The Tnf- $\alpha$ (-308g/A) And IL-6 $(-174 \mathrm{~g} / \mathrm{C})$ Genes On Therapeutic Response To Etanercept In Rheumatoid Arthritis. J. Med. Biochem. 2015, 34, 414-421. [CrossRef] [PubMed]

43. Fabris, M.; Quartuccio, L.; Lombardi, S.; Benucci, M.; Manfredi, M.; Saracco, M.; Atzeni, F.; Morassi, P.; Cimmino, M.; Pontarini, E.; et al. Study on the possible role of the -174G > C IL-6 promoter polymorphism in predicting response to rituximab in rheumatoid arthritis. Reumatismo 2011, 62, 253-258. [CrossRef] [PubMed]

44. Fabris, M.; Quartuccio, L.; Lombardi, S.; Saracco, M.; Atzeni, F.; Carletto, A.; Cimmino, M.; Fabro, C.; Pontarini, E.; Pellerito, R.; et al. The CC homozygosis of the -174G>C IL-6 polymorphism predicts a lower efficacy of rituximab therapy in rheumatoid arthritis. Autoimmun. Rev. 2012, 11, 315-320. [CrossRef] [PubMed]

45. Ruyssen-Witrand, A.; Rouanet, S.; Combe, B.; Dougados, M.; Le Loët, X.; Sibilia, J.; Tebib, J.; Mariette, X.; Constantin, A. Fc $\gamma$ receptor type IIIA polymorphism influences treatment outcomes in patients with rheumatoid arthritis treated with rituximab. Ann. Rheum. Dis. 2012, 71, 875-877. [CrossRef]

46. Kastbom, A.; Cöster, L.; Arlestig, L.; Chatzidionysiou, K.; Van Vollenhoven, R.F.; Padyukov, L.; Rantapää-Dahlqvist, S.; Saevarsdottir, S. Influence of FCGR3A genotype on the therapeutic response to rituximab in rheumatoid arthritis: An observational cohort study. BMJ Open 2012, 2, e001524. [CrossRef]

47. Quartuccio, L.; Fabris, M.; Pontarini, E.; Salvin, S.; Zabotti, A.; Benucci, M.; Manfredi, M.; Biasi, D.; Ravagnani, V.; Atzeni, F.; et al. The 158VV Fcgamma receptor 3A genotype is associated with response to rituximab in rheumatoid arthritis: Results of an Italian multicentre study. Ann. Rheum. Dis. 2014, 73, 716-721. [CrossRef] 
48. Pál, I.; Szamosi, S.; Hodosi, K.; Szekanecz, Z.; Váróczy, L. Effect of Fc $\gamma$-receptor 3a (FCGR3A) gene polymorphisms on rituximab therapy in Hungarian patients with rheumatoid arthritis. RMD Open 2017, 3, e000485. [CrossRef]

49. Daïen, C.I.; Fabre, S.; Rittore, C.; Soler, S.; Daien, V.; Tejedor, G.; Cadart, D.; Molinari, N.; Daurès, J.-P.; Jorgensen, C.; et al. TGF beta1 polymorphisms are candidate predictors of the clinical response to rituximab in rheumatoid arthritis. Jt. Bone Spine 2012, 79, 471-475. [CrossRef]

50. Ruyssen-Witrand, A.; Rouanet, S.; Combe, B.; Dougados, M.; Le Loët, X.; Sibilia, J.; Tebib, J.; Mariette, X.; Constantin, A. Association between $-871 \mathrm{C}>\mathrm{T}$ promoter polymorphism in the B-cell activating factor gene and the response to rituximab in rheumatoid arthritis patients. Rheumatology 2012, 52, 636-641. [CrossRef]

51. Fabris, M.; Quartuccio, L.; Vital, E.; Pontarini, E.; Salvin, S.; Fabro, C.; Zabotti, A.; Benucci, M.; Manfredi, M.; Ravagnani, V.; et al. The TTTT B lymphocyte stimulator promoter haplotype is associated with good response to rituximab therapy in seropositive rheumatoid arthritis resistant to tumor necrosis factor blockers. Arthritis Rheum. 2012, 65, 88-97. [CrossRef] [PubMed]

52. Jiménez Morales, A.; Maldonado-Montoro, M.; Martínez de la Plata, J.E.; Pérez Ramírez, C.; Daddaoua, A.; Alarcón Payer, C.; Expósito Ruiz, M.; García Collado, C. FCGR2A/FCGR3A Gene Polymorphisms and Clinical Variables as Predictors of Response to Tocilizumab and Rituximab in Patients With Rheumatoid Arthritis. J. Clin. Pharm. 2019, 59, 517-531. [CrossRef] [PubMed]

53. Ruderman, E.; Pope, R.M. Drug Insight: Abatacept for the treatment of rheumatoid arthritis. Nat. Clin. Pr. Rheumatol. 2006, 2, 654-660. [CrossRef] [PubMed]

54. Camp, N.J.; Cox, A.; Di Giovine, F.S.; McCabe, D.; Rich, W.; Duff, G.W. Evidence of a pharmacogenomic response to interleukin-1 receptor antagonist in rheumatoid arthritis. Genes Immun. 2005, 6, 467-471. [CrossRef] [PubMed]

(C) 2020 by the authors. Licensee MDPI, Basel, Switzerland. This article is an open access article distributed under the terms and conditions of the Creative Commons Attribution (CC BY) license (http://creativecommons.org/licenses/by/4.0/). 